\title{
Synthesis
}

\section{Reconsidering the Effectiveness of Scientific Tools for Negotiating Local Solutions to Conflicts between Recreation and Conservation with Stakeholders}

\author{
$\underline{\text { Rogier Pouwels }}^{1}, \underline{\text { Paul Opdam }}^{1}$, and René Jochem ${ }^{1}$
}

\begin{abstract}
The conflict between the conservation of biodiversity and recreation activities in the European landscape is intensifying. Managers of large nature areas are confronted with increasing numbers of visitors and decreasing biodiversity values. To accommodate the visitors while simultaneously protecting the biodiversity values they need to make changes in the landscape. Current legislation, a lack of knowledge on the recreation-biodiversity relationship, and the diverging point of view of stakeholders make it difficult to find consensual solutions. New approaches such as adaptive management and boundary management can help managers and stakeholders in the process of decision making. In these approaches the role of scientists has changed, as has the use of their tools. Using two research projects in Europe we explore how scientific tools are used in this new context. We argue that such tools (1) should be built on the interactions between recreation and biodiversity functions, (2) can be used interactively to encourage stakeholders to engage in a learning process, (3) allow local knowledge and data to be incorporated into them, and (4) generate output in the form of a map showing where the conflict areas and opportunities are located. These four key features will help managers to improve communication between themselves, stakeholders, and scientists, increase consensus between stakeholders on how the conflict should be perceived, explore solutions, and generate new knowledge. For future research we suggest investigating how adaptive management and boundary management can be used in a stepwise learning strategy and how uncertainties in the tools affect the learning process.
\end{abstract}

Key Words: adaptive management; biodiversity; boundary management; integrated tools; learning; local data; recreation; spatially explicit; stakeholders; tools; visualization

\section{INTRODUCTION}

To sustainably manage land for the prevention of resources being lost to future generations, land managers need to minimize negative trade-offs between landscape functions. They may decide to reallocate noncompatible functions by modifying the physical patterns of landscapes on which these functions depend. In doing so, managers often affect values attributed to these functions by groups of users, which may lead to conflicts (Young et al. 2005). In this paper we consider the relationship between biodiversity conservation and recreation activities such as walking, cycling, and horse riding in nature areas in Europe. European Union legislation, in particular the Habitats and Birds Directives, is intended to achieve better protection of valuable species and habitats. At the same time, however, health programs are urging the general public to go out into nature areas the EU legislation has been designed to protect. Together with economic developments and demographic trends this has resulted in an increase of recreational use of nature areas (Kerbiriou et al. 2009), and in an increase in the variety of types of outdoor recreation such as hiking, climbing, and canoeing (Naylor et al. 2009). However, there is evidence that stimulating biodiversity conservation and recreation functions of landscapes simultaneously may be incompatible (Young et al. 2005). Recreation activity has been shown to affect vegetation (Liddle 1991) and the population trends of species (Hill et al.
1997, Blanc et al. 2006), especially of birds, e.g., Golden Plover (Pluvialis apricaria; Yalden and Yalden 1990) and Black-tailed Godwit (Limosa limosa; Holm and Laursen 2009). Hence, nature managers find themselves confronted with a potential land use conflict between conservation and recreation activities.

Various options are available to solve this conflict. The managers of nature reserves are statutorily required to create conditions conducive for target species. To achieve this aim they may close parts of the area to visitors, improve habitats to increase the carrying capacity for target species, or construct new parking facilities to redistribute visitor pressure. However, current legislation on biodiversity conservation may restrict such options (Stankey et al. 2005, Williams et al. 2007). In addition, certain options risk alienating visitors; for example, physical adaptations to improve the habitat of species like cutting trees and raising groundwater levels may be perceived as negative by visitors (van Marwijk 2008), and most people engaging in outdoor activities are not aware of their impact on wildlife (Blanc et al. 2006) and are unwilling to accept trail closures.

Thus, nature managers and recreation stakeholders may have opposing views about biodiversity conservation plans and actions, and nature managers and biodiversity conservationists may disagree about recreation plans and actions. To resolve 
this dilemma between recreational development and biodiversity conservation, scientists, policy makers, local managers, and user groups must together seek a solution (Cash et al. 2003). Scientists can contribute to conflict management by providing objective information (Young et al. 2005) and helping to justify management plans and actions (McCool et al. 2007). However, they are hampered by a shortage of knowledge, the inadequacy of their approaches, and the inaccuracy of their tools (Sutherland 2007; S. McCool, unpublished manuscript, http://umontana.academia.edu/Steve McCool/Papers/395214/Outdoor Recreation in the

New Century Frameworks for Working Through the Challenges ). The major gaps in knowledge concern visitors' spatial use of nature areas (Gimblett and Skov-Petersen 2008), the impact of visitors on biodiversity values at the landscape scale (Cole 2006, Sutherland 2007), and the effectiveness of measures to influence the trade-off between biodiversity conservation and recreational use (Wilhere 2002, Cole 2006). Despite having shortcomings, scientific tools such as knowledge systems, simulation models, and agent-based models have proved to be helpful in recreation management (Cole 2005, Gimblett and Skov-Petersen 2008). They have not only helped elucidate current visitor use and find management alternatives that better accommodated recreation-biodiversity combinations, but have also been important for communicating the implications of decisions (Cole 2005, McCool et al. 2007, Gimblett and Skov-Petersen 2008).

However, in the context of the emerging knowledge society (Nowotny et al. 2001), the effectiveness of such tools needs reconsideration. The role of science as a credible provider of irrefutable knowledge is being questioned (Hanssen et al. 2009). Stakeholders are becoming more involved in deciding about land use issues (Young et al. 2005) and often have a good knowledge of local history and conditions. Compared with scientists these stakeholders have opposing opinions about what should or should not be considered as a problem (Cole 2006, Fry et al. 2007) and know how to use the law to their advantage to preclude changes they consider undesirable. They exploit the uncertainties inherent in scientific tools when arguing their case (McCool et al. 2007) and question the credibility of the tools, even those built in accordance with quality standards (e.g., Refsgaard and Henriksen 2004, Brown 2006). In this paper, we therefore reconsider the effectiveness of current scientific tools in recreation-biodiversity conflict management as a part of a learning strategy of facilitation and pacification (Hanssen et al. 2009). We will identify the requirements of scientific tools for conflict management in the conceptual framework of adaptive management (McCool et al. 2007, Williams et al. 2007) and boundary management (Cash et al. 2003), and will illustrate their importance by drawing upon a recent application in a research project in northwest Europe.

\section{NEW RECREATION MANAGEMENT APPROACHES}

The recreation-biodiversity conflict is complicated by high levels of uncertainty and lack of consensus among parties about how to combine the conflicting landscape functions in nature areas (Young et al. 2005). To solve this type of conflict, two strategies have been proposed (Hanssen et al. 2009). The first, the pacification strategy, entails conducting research to decrease uncertainties, with the aim of enhancing consensusbuilding about solutions. The second, the facilitation strategy, entails building consensus about beliefs, ambitions, and directions of solutions before starting research to decrease the uncertainties. Managers can opt for the pacification strategy by following an adaptive management approach, and the facilitation strategy by following a boundary management approach (Fig. 1).

Fig. 1. Managing the recreation-biodiversity conflict with the frameworks of adaptive management and boundary management. Figure modified from Hanssen et al. (2009).

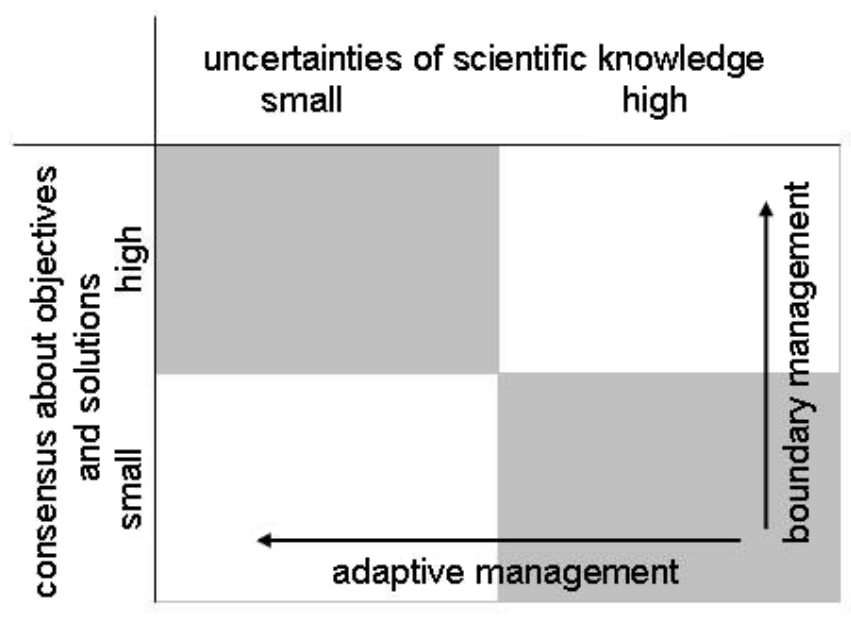

Adaptive management is an appropriate approach in the event that the involved parties are in agreement about the nature and extent of the problem, although it is uncertain whether the chosen measures will be effective because of uncertainty in knowledge or unpredictability of the system response (Williams et al. 2007). Influencing recreation behavior has highly uncertain outcomes (Cole et al. 1987, Cole 2006), and recreation-biodiversity relationships are poorly understood (Sutherland 2007). Under these conditions, adaptive management provides a proper approach to deal with uncertainty. In using scientific tools, their uncertainty needs to be known.

However, adaptive management is not designed to resolve conflicts about management objectives (Williams et al. 2007). In biodiversity-recreation interactions, there is often disagreement about the problem. In most cases recreation does not lead to direct death of individual animals; what makes it 
hard for recreation stakeholders to accept is that populations might be at risk because of high levels of visitors. In the event that the nature and the cause of a conflict is in debate, and at the same time the degree of uncertainty about effective solutions is high, the management strategy needs to be based on communication, translocation, and mediation (Cash et al. 2003). This so-called boundary management is considered an appropriate approach if the agreement on the impact of management options is low. Cash et al. (2003) proposed that in using scientific tools to transfer information, credibility, saliency, and legitimacy of information are critical factors to enhance.

Current recreation management approaches often show characteristics of adaptive management (Nilsen and Tayler 1997, McCool et al. 2007). Scientific tools are used to compare the possible effect of alternative solutions. In contact with stakeholders, these tools are typically used in a one-way direction to inform stakeholders about changes in management. However, boundary management requires that stakeholders are actively involved in the development and use of scientific knowledge and tools. Knowledge held by stakeholders is regarded as a valuable part of the knowledge base that should be shared in a common process of fact finding and design of solutions, and to decrease uncertainty. There is therefore a need for tools that can support both adaptive management and boundary management, developed in accordance with the demands of transdisciplinary research (Thompson Klein 2004). We propose using four guiding principles for this.

First, the tools must be able to cross the boundary between recreation and biodiversity. They must therefore be built around the recreation-biodiversity relationship and distinguish between parts of the relationship that are objective, e.g., the measured distances birds fly when disturbed by a visitor, and those that are subjective, e.g., the species chosen as a conservation target (Termorshuizen and Opdam 2009). The tools need to have "the right control knobs," which are compatible with the type of management action that managers can take.

Second, scientific tools must be able to support the engagement of stakeholders in a process of learning about the system and how recreation and biodiversity are interrelated (Margerum 2002). The tools need to be helpful in moderating the participation of stakeholders in the process in an interactive way, so that scientists, stakeholders, and managers can learn from one another. The participation of all actors in shared meetings will help actors on opposing sides to understand the relationship between recreation and biodiversity functions and how this relationship is related to each other's values (Lamers et al. 2010).

Third, the tools must be accepted as credible and legitimate in the local context (Cash et al. 2003) by both managers and stakeholder groups. Therefore the tools should be able to incorporate local knowledge and to be adjusted to improve their match with local conditions. Local knowledge could fill in knowledge gaps in the tool, and by experimenting with them local users may learn to discover the structure of the tools and the underlying assumptions, and thereby become able to judge the appropriateness of the tools for their case and their interests.

Fourth, tools should guide toward solutions by providing room to maneuver between possibilities and constraints (HorlickJones and Sime 2004). The tools should support the negotiating actors in finding a new design that solves the problem, takes full advantage of the opportunities of the area, and is socially acceptable. The tools should be capable of generating local maps showing these opportunities and conflicts.

We summarize these demands as the following four key features:

1. The tool is built on the relationship between recreation and biodiversity functions;

2. The tool can be used in an interactive way in a learning process to clarify the conflict;

3. The tool can be made context-specific with local data and knowledge;

4. The tool is based on spatially explicit relationships and its output is a map showing where measures can be taken.

\section{USING SCIENTIFIC TOOLS IN THE RECREATION- BIODIVERSITY CONFLICT}

To demonstrate and to discuss the importance of the four key features we will describe our experience with the use of scientific tools in a recent research project. The PROGRESS project took place from October 2003 until October 2007 (see www.forestry.gov.uk/forestry/infd-6aqeua). The research was conducted in the New Forest, which covers $>57,000$ ha west of Southampton, UK. Centuries of grazing by deer and livestock, coupled with human management shaped the forest into a combination of heathland, ancient woodland, mire systems, grassy plains, and coniferous and deciduous enclosures. As part of the Natura 2000 network in Europe the New Forest is protected by the Habitat Directive (Council Directive 92/43/EEC) and the Bird Directive (Council Directive 79/409/EEC). These nature conservation legislations should safeguard natural values and stop the decline of biodiversity in the EU. Both directives also state that measures taken for this protection should take into account economic, social, recreational, and cultural requirements. For the New Forest recreation is important because it supports economically significant tourism industries in its surroundings. Over the last three decades the New Forest has experienced a significant rise in visitor numbers, and the 
Fig. 2. Example of management tool containing scientific tools for recreation and for biodiversity (adapted from Pouwels et al. 2008). The inputs are GIS maps containing landscape characteristics and attributes managers can control. The outputs are indicators that can be linked to objectives. The black arrow between the recreation tool and the biodiversity tool indicates the ecological footprint of recreation. The grey arrows indicate possible interactions between biodiversity values and recreation that have not yet been integrated, like the added value of a singing Sky Lark (Alauda arvensis) for visitors.

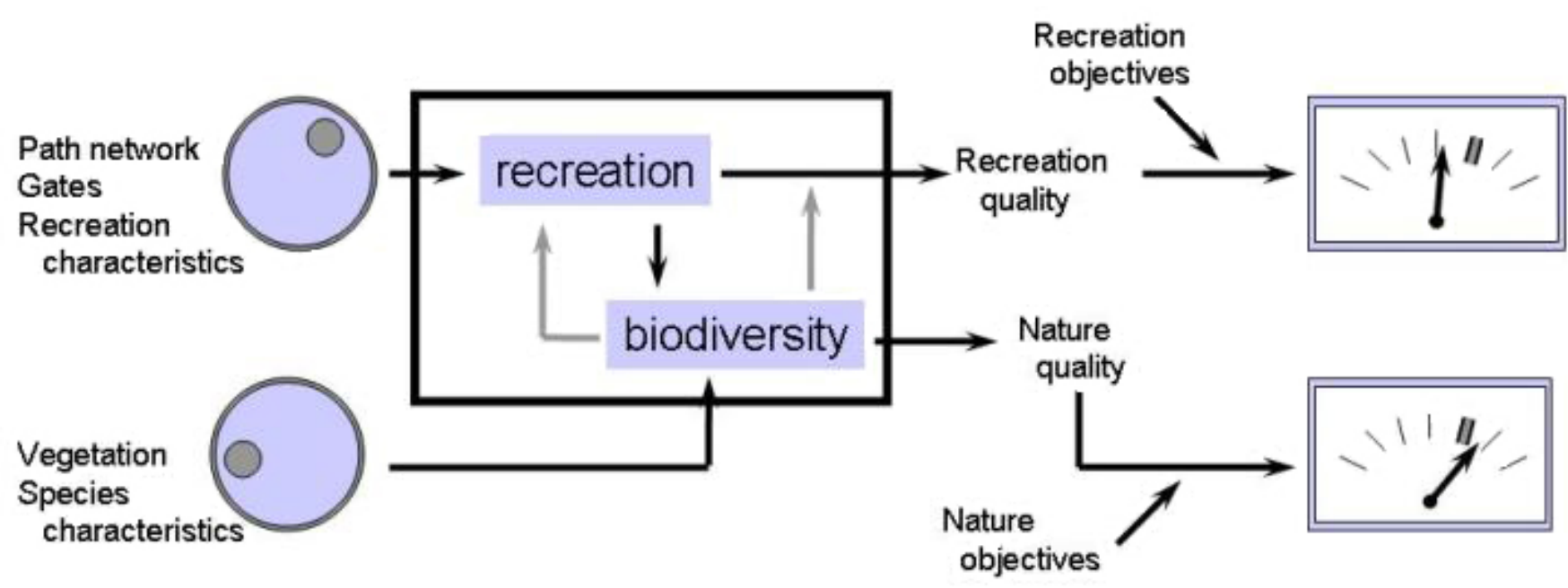

estimation of more than 13.5 million visitors each year could pose a serious potential threat to the biodiversity of the area. As a result the land managers are looking for solutions together with scientists, local experts, and local stakeholders (Colas et al. 2008). The Forestry Commission consults a local stakeholder network about its activities.

In the PROGRESS project we built on this network. Apart from informing the public and trying to influence their behavior, the project organized a dialogue with a panel of 23 stakeholders to use local knowledge in finding solutions for nature-recreation conflicts and guide the direction of the project actions. These stakeholders represent different interest groups, e.g., local councils, conservation groups like The Royal Society for the Protection of Birds (RSPB), and recreational user groups (Table 1). The Verderers have a specific role among the stakeholders because they share the responsibility for the management of the New Forest together with the Forestry Commission. The Verderers derive their offices, powers, and responsibilities from the Act of Parliament in 1877 and are elected by the county. In meetings they were represented by up to three people. For the Forestry Commission the local input of the stakeholders is vital in sharing many management decisions and in fostering a more comprehensive understanding of forest issues and just as importantly, other peoples' views (see www.forestry.gov.uk/ forestry/INFD-6A5LAC). The role of the scientists involved was to facilitate and mediate. The team consisted of a social scientist, a conservation scientist, and a model engineer. Also a local scientist played an important role. He was an employee of the Forestry Commission and could therefore be regarded as a stakeholder.

During the project the role of the stakeholders in the New Forest took many forms (Lamers et al. 2010) and varied between meetings. According to the IAP2 Spectrum developed by the International Association for Public Participation (Ritzema et al. 2010) the role of the stakeholders evolved during the project from being informed to full decision making. At the start of the project the choice for the tools was made by the scientists and the managers and the stakeholders were informed. The stakeholders were consulted when conflicts between recreation, e.g., walking and cycling, and biodiversity, e.g., protected bird species, might occur and on how they could be solved. This consultation resulted in proposals for the locations of pilot actions the managers could implement like closing car parks, closing car parks only during breeding season, improving habitats of wader species, increasing awareness of visitors by signs of the sensitive areas, and rerouting the path network. The proposals combined the stakeholders' local knowledge of the area with scientific knowledge in such a way that site specific solutions could be found. The scientific tools were used to predict the effects of the proposed pilot actions on recreational values and biodiversity values. Predictions of the impact of pilot actions were shown on maps and discussed at public engagement events. During these events inhabitants of the area sometimes backed up the results and sometimes they disagreed. Finally 
Table 1. Stakeholders involved in the PROGRESS project in alphabetic order. Together with the Forestry Commission they discussed the management alternatives and made decisions about the pilot actions.

\begin{tabular}{|c|c|c|}
\hline Stakeholder & Website & Description \\
\hline Beaulieu Settled Estate & & Private estate in the New Forest \\
\hline British Horse Society & www.bhs.org.uk & The UK's largest equestrian charity with over 60,000 members \\
\hline $\begin{array}{l}\text { Camping and Caravanning } \\
\text { Club }\end{array}$ & $\begin{array}{l}\text { www.campingandcaravanningclub. } \\
\text { co.uk }\end{array}$ & $\begin{array}{l}\text { The oldest and largest camping club in the UK, offering Club sites } \\
\text { across the country }\end{array}$ \\
\hline Countryside Agency & www.defra.gov.uk/crc/ & UK public body working to improve the quality of the countryside \\
\hline Natural England & www.naturalengland.org.uk/ & $\begin{array}{l}\text { Government agency set up by the Department of Environment, Food } \\
\text { and Rural Affairs to conserve wildlife, geology, and wild places in } \\
\text { England }\end{array}$ \\
\hline Hampshire County Council & www.hants.gov.uk & Regional Government office \\
\hline Hampshire Wildlife Trust & www.hwt.org.uk & Wildlife charity for Hampshire and the Isle of Wight \\
\hline Livery Representative & & Representing local livery yards and small riding stables \\
\hline National Trust & www.nationaltrust.org.uk & $\begin{array}{l}\text { Charity working toward conserving the UK's countryside and } \\
\text { heritage through protecting the environment }\end{array}$ \\
\hline $\begin{array}{l}\text { New Forest Commoners' } \\
\text { Defence Association }\end{array}$ & $\underline{\text { www.newforestcommoners.co.uk }}$ & $\begin{array}{l}\text { Organization that supports the rights of New Forest commoners to } \\
\text { turn their stock out on the open Forest }\end{array}$ \\
\hline $\begin{array}{l}\text { New Forest District } \\
\text { Council }\end{array}$ & $\underline{\text { www.nfdc.gov.uk }}$ & Local Government office \\
\hline $\begin{array}{l}\text { New Forest Equestrian } \\
\text { Association }\end{array}$ & www.nfed.co.uk/nfea.htm & $\begin{array}{l}\text { Organization working toward preserving the tradition of freedom to } \\
\text { ride in the New Forest }\end{array}$ \\
\hline New Forest Access Forum & $\begin{array}{l}\text { www.newforestnpa.gov.uk/looking- } \\
\underline{\text { after/new-forest-access-forum }}\end{array}$ & $\begin{array}{l}\text { Advisory body of New Forest professionals looking to improve } \\
\text { access to the countryside }\end{array}$ \\
\hline NEWFORCE & www.newforce.org.uk/ & New Forest off-road cycling club \\
\hline $\begin{array}{l}\text { New Forest Association of } \\
\text { Local Councils }\end{array}$ & & $\begin{array}{l}\text { An association that represents the interests of the local councils based } \\
\text { in the Forest }\end{array}$ \\
\hline National Park Authority & $\underline{\text { www.newforestnpa.gov.uk/ }}$ & $\begin{array}{l}\text { An association of selected members that act in the interests of the } \\
\text { New National Park }\end{array}$ \\
\hline $\begin{array}{l}\text { New Forest Dog Owners' } \\
\text { Group }\end{array}$ & http://www.newforestdog.org.uk/ & $\begin{array}{l}\text { Organization working toward the rights of dogs and their owners in } \\
\text { the New Forest }\end{array}$ \\
\hline $\begin{array}{l}\text { New Forest Tourism } \\
\text { Association }\end{array}$ & & A group consisting of all the local tourism providers \\
\hline New Forest Association & $\underline{\text { www.newforest-online.co.uk/ }}$ & $\begin{array}{l}\text { An independent organization dedicated to protecting the traditional } \\
\text { character in the New Forest }\end{array}$ \\
\hline Ramblers' Association & www.ramblers.org.uk & UK charity looking after footpaths and the countryside for walkers \\
\hline RSPB & www.rspb.org.uk & $\begin{array}{l}\text { UK charity working to secure a healthy environment for birds and } \\
\text { wildlife }\end{array}$ \\
\hline SUSTRANS & $\underline{\text { www.sustrans.org.uk }}$ & $\begin{array}{l}\text { A charity that encourages people to walk, cycle, and use public } \\
\text { transport }\end{array}$ \\
\hline Verderers & $\underline{\text { www.verderers.org.uk }}$ & $\begin{array}{l}\text { A statutory body that shares the management of the New Forest with } \\
\text { the Forestry Commission }\end{array}$ \\
\hline
\end{tabular}

the stakeholders decided to agree with four of the proposed pilot actions and disagree with one.

\section{Integrating the recreation tool and biodiversity tool}

To be salient, the tools must clarify the recreation-biodiversity relationship in a way that opens up perspectives for action (Sutherland 2007). The integrated recreation-biodiversity tool enables managers to model the functional relationships between the attributes they can control in one domain and the outcomes they seek in the other domain. In the project, the recreation tools had to evaluate the impact of changes in the path network, parking lots, and recreation characteristics on recreation patterns and objectives. The biodiversity tool had to evaluate the impact of changes in the recreation patterns and vegetation structure on habitat quality for species and biodiversity objectives. In other words, the managers had to be able to make minor adjustments using the right "tuning knobs" (Fig. 2).

Because the interaction between recreation and biodiversity is often the main source of conflict, the way this interaction is implemented in the tools has to be made transparent. Also, uncertainties, or disagreements, about resources, parameter setting, and management effects have to be made explicit (Williams et al. 2007, Itami et al. 2008). At present, the only 
examples available are of recreation tools and biodiversity tools that are partly integrated (e.g., Mallord et al. 2007, Coombes et al. 2008, Pouwels et al. 2008). As yet, no tool has been developed to dynamically and concurrently model the behavior of animals and of visitors (see also Skov-Petersen 2008).

In the project we used the Multi-Agent Simulation Of Outdoor Recreation (MASOOR) recreation tool (Jochem et al. 2008) and the Landscape ecological Analysis and Rules for the Configuration of Habitats (LARCH) biodiversity tool (Opdam et al. 2003, Verboom and Pouwels 2004). The MASOOR model is an agent-based model that focuses on the simulation of the behavioral aspects of recreational movement in natural areas. The main task for the agents is to navigate through a network of paths by making choices at each junction and to achieve one or more recreational goals such as visiting a certain point of attraction, or walking for 2 hours. MASOOR predicts the densities of visitors on each path section and the number of encounters between different types of visitors. The LARCH model is used to determine the viability of landscapes for species. It uses different parameters for each species. Habitat is selected from vegetation maps. Suitability for local populations is determined using species-specific area requirements. The recreation tool and biodiversity tool were not fully integrated into a single interactive tool. The results generated by the recreation tool had to be translated into a recreation impact using a GIS. The map showing the recreation impact was inserted into the biodiversity tool during an interactive session. Combining the tools in this way made it possible for managers to discuss with stakeholders the impact of changes in the recreation pattern, e.g. of parking lots or on the habitat quality of wader species. This allowed them to decide which of the management alternatives would positively impact wader habitats (see Colas et al. 2008 for more information). Users said that the tools could be made more user-friendly by integrating both tools into one management tool.

\section{The tool facilitates communication and helps clarify the underlying conflict}

To serve as boundary objects (Star and Griesemer 1989), scientific tools should help clarify underlying conflicts and create understanding of the issues at stake. One of the benefits of simulation tools such as MASOOR is that users can actually see visitors moving across a dense path network (Online Resource 1). The animation interface projected the results on aerial photographs and gave managers and stakeholders the impression that they could play with it like a computer game. Stakeholders familiar with the area will recognize the output and can get used to the tools (Kleijnen 1995), which makes it easier for them to participate in the process.

During interactive sessions with managers and stakeholders the animation tool helped us as scientists to explain the main processes simulated by the tool. Stakeholders reflected on what the tool showed, described the process from their own perspective, and specified their values, concerns, and way of thinking. This added valuable knowledge to the development of the tool, e.g., the effect of crowding was left out because stakeholders indicated that in the New Forest this had a minor effect on visitors' use of the area. As we started to discuss the main processes and parameters in the scientific tools with managers and stakeholders, they started to give feedback on how they perceived the processes underlying the conflict. In this process, all actors learned each other's values and began to understand more about the world on the other side of the table. This increased the credibility and legitimacy of the tools (Cash et al. 2003, Lynam et al. 2002, Fry et al. 2007). As an illustration, recreation stakeholders learned that seeing birds still present in the area is not a guarantee they are not being disturbed and biodiversity stakeholders learned why visitors like to follow some specific routes, such as a former railroad.

\section{Adaptation to local data and knowledge}

Adapting existing scientific tools in the light of local data will increase the reliability of their output as well as their credibility (Irvine et al. 2009), especially if the data were gathered in collaborative monitoring projects (Fernandez-Gimenez et al. 2008), because stakeholders can see how a tool deals with their local data. They can then respond to the output, improve it, and incorporate the tool into their mindset. However, most scientific tools are developed for specific case studies, which makes it difficult to apply them elsewhere (Sturtevant et al. 2007). It saves costs and developing time if tools are developed with modular architecture (Maxwell and Costanza 1997, Scheller et al. 2007) and with a separate database. Modular architecture allows new processes to be incorporated by making minor additions or adjustments to the tool. A separate database for each parameter makes it possible to change settings during interactive sessions, without making changes to the tool itself. Because both the MASOOR and LARCH tool have this modular structure, they are flexible in incorporating specific local conditions.

In the New Forest the LARCH tool was adapted by adding the slope of the land as extra input for determining the habitat of wader species. One of the adaptations made to the MASOOR tool was to remove the effect of crowding (e.g., Arnberger and Mann 2008) because stakeholders and managers expected this to have a minor effect on visitors' use of the area. At first the local scientist was very skeptical about using tools to predict potential bird distributions. However, after the biodiversity tool had been adapted in light of his local knowledge and he had been shown how the model's predictions improved as a result of inputting information he supplied (Fig. 3), he became an advocate of the use of scientific tools in stakeholder meetings. Legitimacy was gained because the local scientist affirmed that the tools reflected the local situation. Thanks to his detailed knowledge of the area he was able to discuss local 
Fig. 3. Map showing the potential habitat for wader species in part of the New Forest. The map used generic knowledge of habitat preferences from the database of the biodiversity tool LARCH (Opdam et al. 2003, Verboom and Pouwels 2004), but was amended by adding local monitoring data and information on landscape features in the New Forest that predicted the current and historic distribution of wader species in this area. Based on local maps consisting of vegetation structure and slope the habitat was classified as optimal, suboptimal, and marginal. In optimal habitat wader species can reach high densities and in marginal habitat low densities. The monitoring data had been gathered over several years and included four wader species: Lapwing (Vanellus vanellus), Curlew (Numenius arquata), Snipe (Gallinago gallinago), and Redshank (Tringa totanus).

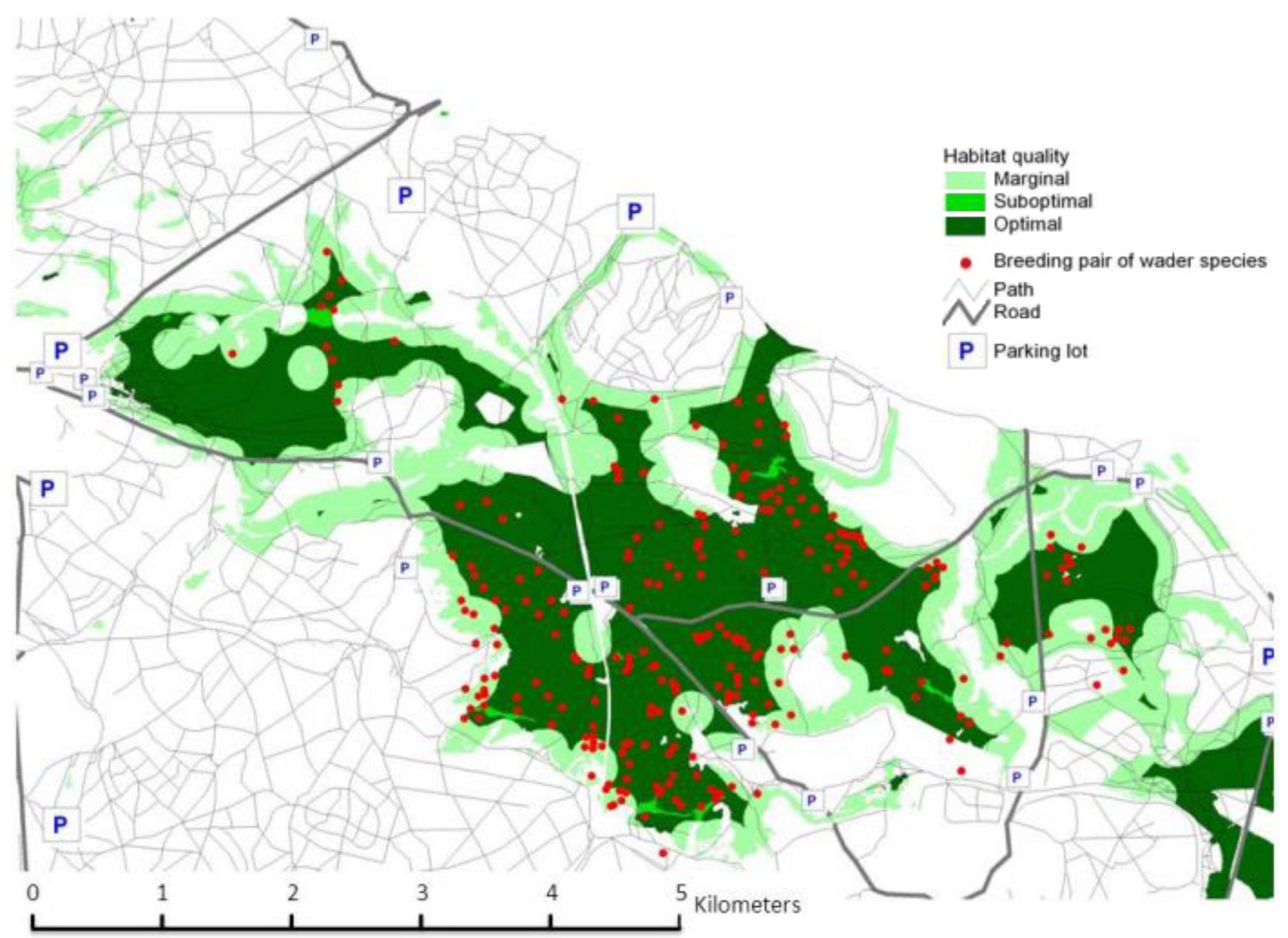

settings with the stakeholders and could clarify the output of the tool in the local context. Thereby he played a crucial role as a key information conduit between the participants, i.e., stakeholders, managers, and the team responsible for modifying the scientific tools (as discussed in Sturtevant et al. 2007).

\section{The tool is based on spatially explicit relationships and its output is a map}

In boundary management it is crucial to be specific about where recreation activities are incompatible with biodiversity conservation. Conflicts are often discussed in general terms (Margerum 2002), neglecting that the intensity of the recreation-biodiversity interaction may vary because of spatial heterogeneity in habitat types, distribution of species, and visitor patterns. Solving the conflict becomes easier when the critical locations are known. We expect that presenting the output as a map showing the nature and intensity of the recreation-biodiversity interactions will enable stakeholders to identify where the problem is located; this may reduce the tension between opposing views. 
Fig. 4. Map of the disturbance zones of visitors overlain on the habitat map of wader species, overlain on an aerial photograph. The easternmost parking lot is shown in red ('P'). Based on local maps consisting of vegetation structure and slope, the habitat was classified as optimal, suboptimal, and marginal. In optimal habitat wader species can reach high densities and in marginal habitat low densities.

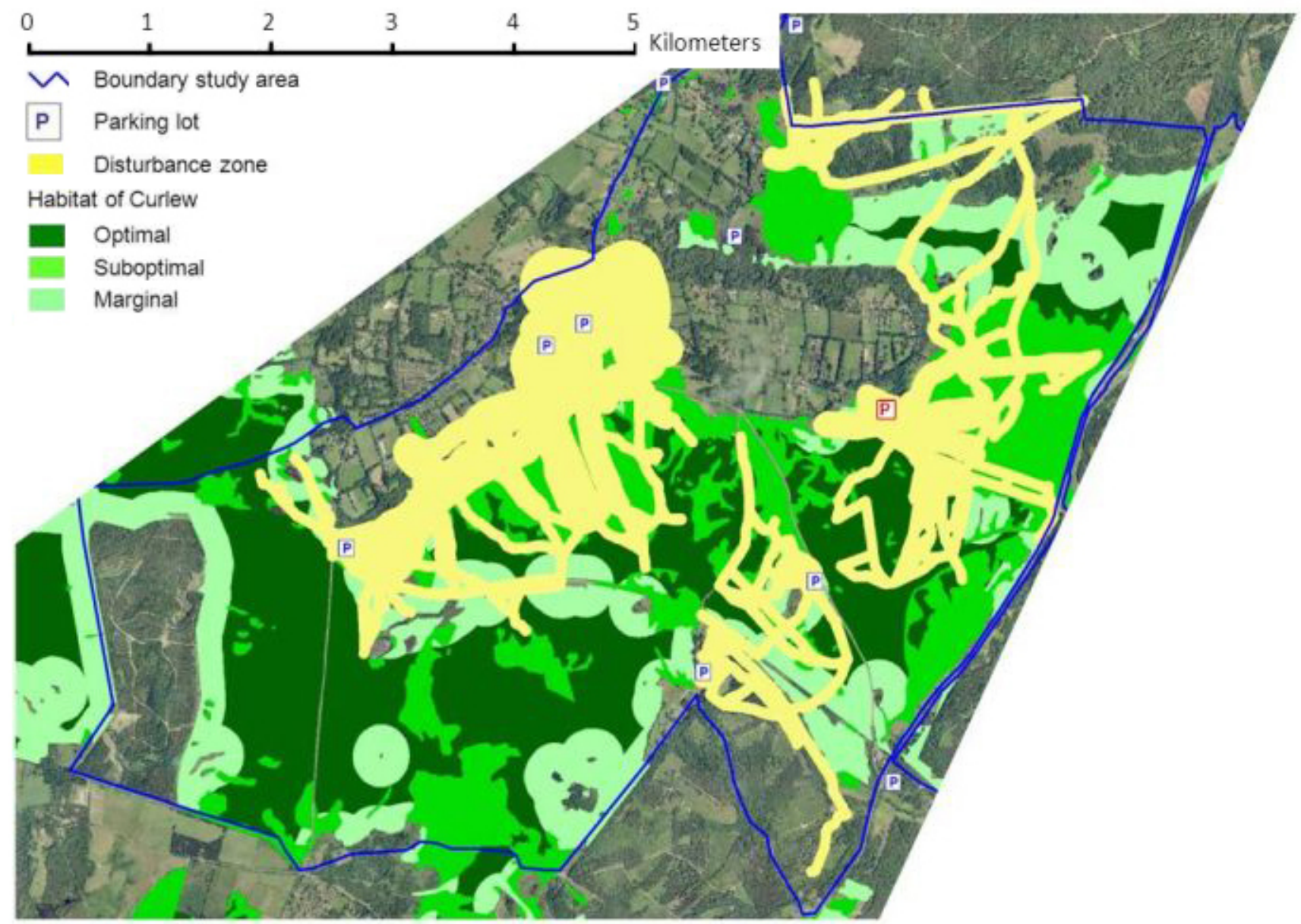

In our projects, to help managers and stakeholders identify obstacles to maintaining recreation and biodiversity values we visualized ecological disturbance zones (Fig. 4). In the New Forest, managers used the resulting map to discuss management alternatives with stakeholders. It became obvious that the easternmost parking lot had a much greater impact on the habitat quality of wader species than the other parking lots. On the basis of this spatial information, stakeholders agreed on decommissioning the parking lot. Based on the same map, the park managers also found opportunities to increase the capacity of two nearby parking lots without affecting the habitat quality elsewhere. Depicting recreation pressure to stakeholders visually in this way improved their acceptance of the decisions made (Colas et al.
2008). Our findings are in accordance with Skov-Petersen (2008) and Jochem et al. (2008) who combined scientific tools with a GIS and Google Maps to increase the usability of the scientific tools in a participatory process.

\section{DISCUSSION}

The participatory modeling in the PROGRESS project contributed to conflict resolution in a system with many uncertainties by combining elements of adaptive management and boundary management. We went through a collaborative learning process in which scientists and interest groups developed a common understanding of the local biodiversityrecreation system by combining generic scientific knowledge with specific knowledge of the local context. This resulted in an agreement about the problem that had to be solved and the 
solution that was most appropriate in the local situation. In this process the models played a key role as a means to learn and communicate the underlying mechanisms in the biodiversity-recreation relationship, which formed the basis for identifying the problem and designing the solution. As such, we applied the mix of objectives suggested by Voinov and Bousquet (2010), Souchère et al. (2010) and Simon and Etienne (2010). Previously, Pröbstl et al. (2008), Marceau (2008), and Jochem et al. (2008) emphasized the role of recreation tools in mutual learning, but did not consider their effectiveness for boundary management in conflict solving. Because the relationship between scientist, managers, and stakeholders in boundary management is fundamentally different from the relationship in mutual learning without conflicts, it is important to reconsider the design of tools from a perspective of effectiveness in solving problems that have a high degree of uncertainty.

\section{Uncertainty}

In assessing environmental conditions, different types of uncertainties have been distinguished (Brugnach et al. 2008, Opdam et al. 2009). Incomplete knowledge is uncertainty due to lack of sufficient scientific proof, unpredictability is uncertainty caused by the stochastic behavior of the system under observation, and ambiguity is due to low uniformity in societal values and norms. The impacts of these sources of uncertainty on conflict solving are largely unexplored. Incomplete knowledge seems to be managed in adaptive management, whereas boundary management specifically aims to manage ambiguity. During the PROGRESS project we encountered uncertainties regarding incomplete knowledge and ambiguity several times. Uncertainties related to unpredictability were less present. Although we didn't analyze their impact on the common learning process at that time, we can reflect on the way we dealt with uncertainty in the various steps of the process in retrospect. The three criteria for effective transfer of scientific knowledge in participatory processes suggested by Cash et al. (2003) serve as an appropriate reference.

Only qualitative indications were available concerning the cause of the conflict, the decline of birds due to an increase in recreation. This influenced a number of choices we made, and in retrospect these can be considered as part of a strategy to minimize the impact of uncertainty on the credibility of scientific information. When choosing indicator species for biodiversity, managers want to be sure pilot actions will result in increasing population numbers. From a political point of view Natura 2000 species would be good indicator species. However, Kingfisher (Alcedo atthis) and Honey-buzzard (Pernis apivorus) probably will not profit from pilot actions because there is little overlap between suitable habitat for the Kingfisher and the current path network, and the population of the Honey-buzzard is so small that effects cannot be detected. Effects of pilot actions on the populations of Dartford
Warbler (Sylvia undata) and Nightjar (Caprimulgus europaeus) will also be difficult to detect because these are already increasing, probably because of climate change. Also stakeholders might disapprove with changes in the landscape for species that already flourish. We did expect effects of pilot actions on population of Wood Lark (Lullula arborea). However, this species is breeding at large parking lots because the vegetation structure is optimal habitat. It would be very difficult to convince stakeholders that Wood Larks are affected by visitors. Therefore managers and stakeholders had to choose other indicator species. The chosen wader species are also expected to be sensitive to recreation disturbance and we found a large overlap in suitable habitats and recreational use. Managers were also interested in these species because large restoration projects had not resulted in increasing numbers yet.

Most scientific research on recreation disturbance focuses on walkers and dog owners. There is little research on disturbance by cyclist and horse riders. In the New Forest the largest user groups are also walkers and dog owners. Therefore the managers were able to demonstrate to the stakeholders that it was legitimate to take pilot actions regarding these user groups. To choose suitable locations for pilot actions the managers had to know how these user groups use the area. A large monitoring program was set up, including counting visitors, tracking visitors with GPS devices, questionnaires, and telephone surveys. The GPS tracks especially helped stakeholders to learn about the biodiversity-recreation relationship in the New Forest and decide which pilot actions should be approved.

Imperfect knowledge about the interaction between recreation and biodiversity sometimes resulted in the tools losing credibility. The level of sensitivity of wader species to recreational disturbance was not known and provided an escape route from the common learning process. In adaptive management this type of uncertainty should be embraced and reduced by pilot actions, but it can be argued that if knowledge is in short supply, there is no proof that a problem exists and no guarantee that a chosen solution will be effective in solving it. To reduce the possibility of the easy way out of doing nothing, boundaries between stakeholders and scientists from different disciplines should be crossed. In the project, we discussed the uncertainty with recreation stakeholders and conservationists and agreed that an effect was plausible; for determining cause-effect relations we used scientific knowledge from studies on comparable species and from expert judgment.

In the project ambiguity was the most difficult type of uncertainty. One stakeholder just didn't accept the fact that dogs affect breeding bird densities. In his opinion there were no conflicts. Although the tools were used to visualize relationships between recreation and biodiversity in 
stakeholder meetings and helped other stakeholders to engage further in the participatory process and clarify goals and values, this one stakeholder slowed down the process. In the end a survey among dog owners in the area showed that most dog owners didn't sympathize with this particular stakeholder's vision and arguments. This helped the managers and other stakeholders to neglect some of the arguments of this one stakeholder.

We suggest that incomplete knowledge on the biodiversityrecreation relationship in a spatially explicit landscape context may be key to whether a tool is accepted in conflict resolution because it is at the heart of the conflict. We therefore believe it is important to enlarge the body of knowledge on how recreation and biodiversity values and underlying processes are related (Cole 2006, Haider 2006, Sutherland 2007). Of particular importance are the impact of recreation on species populations, how management measures reduce this impact, and how recreation and biodiversity functions can be spatially combined in landscape planning (Warnken and Buckley 1998, Blanc et al. 2006, Sutherland et al. 2006). Such investigations should be based on better empirical data on recreation behavior (van Marwijk 2009), for example, on the motives of visitors, their perception of the landscape, and the choices they make during their visit. The results might endorse management measures for achieving a more compatible recreation pattern.

As a topic of future research, we suggest investigating how the three types of uncertainties can be managed in adaptive management or boundary management. As a hypothesis, we propose that boundary management deals better with uncertainties related to ambiguity whereas adaptive management deals better with uncertainties related to incomplete knowledge (Fig. 5). Therefore we recommend that managing the recreation-biodiversity conflict should alternate between a pacification strategy and a facilitation strategy (Fig. 1). This option can be considered as a stepwise learning strategy of adaptive management, focused on dealing with uncertainties related to incomplete knowledge (Williams et al. 2007), and boundary management, focused on dealing with opposing views on the conflict and preferable solutions (Cash et al. 2003). The research should explore the possibility of discovering if the way uncertainties are clarified in the tools affects the learning process.

\section{Complexity of the model}

In conflict situations, tools may be rejected for various reasons because participants do not want to cooperate in finding a solution. Simple tools can be rejected because they are less precise and do not exactly describe the local situation; this makes an easy argument to a local stakeholder to reject the tool for lack of credibility. Complex tools may be rejected because they are not transparent and therefore not recognized as legitimate. Therefore, the creation of trust during boundary management is crucial for having models accepted as reliable sources of information, most importantly if complex tools are used (Voinov and Bousquet 2010). If the tools are flexible and adjustable to the local situation (Voinov and Bousquet 2010), their information is more credible to local users. Legitimacy and credibility are gained when models are selected because they have been used in comparable areas for comparable conflicts (Ritzema et al. 2010). In some situations complex tools might be rejected but the final results accepted (Lagabrielle et al. 2010), and developing and using the tools will be a means and not an end (Farolfi et al. 2010).

Fig. 5. Schematic representation types of uncertainties (Brugnach et al. 2008, Opdam et al. 2009) and the degree to which they are addressed in boundary management and adaptive management.

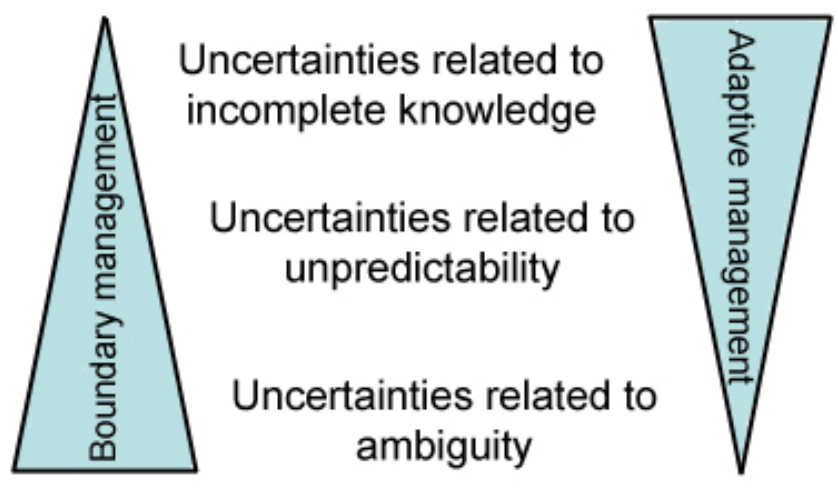

In boundary management it is relevant that the risk of rejecting information because it is considered untrustworthy is lower when the stakeholders are involved in the development of the scientific tools from the start. However when means are scarce it is difficult to develop a complete new tool. It's better to use existing tools and adjust them. Which tools will be used is again preferably a decision for the stakeholders, but in most situations the choice is made by the scientists (Voinov and Bousquet 2010). In the PROGRESS project the choice was made by the scientists and the managers because the scientists preferred the tools they had developed and used. The stakeholders accepted the tools because we started with a reflection in the first stakeholder meeting and the development of the tools during the project was an iterative cycle (Farolfi et al. 2010). In these meetings we explained the concepts behind the tools. In this way the tools were used to cross the boundary between recreation and biodiversity (Lamers et al. 2010). In some cases the use of the tools for evaluating management alternatives is less important than the discussion of the results (Voinov and Bousquet 2010, Itami 2008).

The biodiversity tool LARCH that we used in the PROGRESS project was simple compared with the recreation tool 
MASOOR. LARCH predicts potential suitable habitats for species in three classes based on four landscape characteristics. The tool does not model the population processes, but uses thresholds that are related to these processes (Verboom et al. 2001, Opdam et al. 2003). We think LARCH was accepted by the managers and stakeholders because the results were credible when compared to local knowledge and data, and the tool was salient and legitimate because it was simple and easy to understand. The MASOOR model is rather complex for lay people because it is based on a Hierarchical Control System in which agents interpret the world at different scales and autonomously navigate a given recreational track network. The navigation of the agents in the landscape is a random process based on multicriteria analysis using the preferences of the agents for the characteristics of the landscape, the goals agents try to reach, and the already followed route (Jochem et al. 2008). It is difficult for people to fully understand what the consequences are for the results when some parameters and equations will change. We think the most important reason for managers and stakeholders to accept MASOOR is the animated results. We also used a simple algorithm for predicting the use of visitors, but the managers and stakeholders chose the more complex tool because it was more salient. Legitimacy was gained in one of the meetings when an example of the results of MASOOR was presented. One of the stakeholders in the New Forest remarked, "that's the exact route I always take." This simple remark led to the acceptance of almost every stakeholder present.

We have addressed how scientific tools can be made more effective in helping solutions to be found for common conflicts between biodiversity and recreation functions. We discussed how four proposed features of interactive tools enhanced understanding of the other side's viewpoint, helped clarify the conflict, and assisted in exploring solutions. To achieve this, a tool needs to be built on the relationship between recreation and biodiversity functions, and be able to incorporate local knowledge and data. We also found that conflict resolution is enhanced by showing the model output as a map indicating where the conflict is located and where opportunities for solving the conflict can be created. These features could have a more general significance for understanding the role of tools in conflict management. We hope that future research can build on our insights to ensure that scientific tools not only facilitate communication in adaptive management, but also for the generation of new common knowledge that is so crucial for boundary management.

\section{RESPONSES TO THIS ARTICLE}

Responses to this article are invited. If accepted for publication, your response will be hyperlinked to the article. To submit a response, follow this link. To read responses already accepted, follow this link.

\section{ACKNOWLEDGMENTS}

This paper is a joint product of the PROGRESS project funded by EU Interreg IIIB and the strategic research program "Sustainable spatial development of ecosystems, landscapes, seas and regions" which is funded by the Dutch Ministry of Agriculture, Nature Conservation and Food Quality, and carried out by Wageningen University \& Research Centre. The authors thank the project members from the Forestry Commission and Alterra for their discussions on the subject and Joy Burrough for her editorial improvements.

\section{LITERATURE CITED}

Arnberger, A., and C. Mann. 2008. Crowding in European forests: a review of recent research and implications for forest management and policy. Forestry 81:559-571. http://dx.doi.o $\mathrm{rg} / 10.1093 /$ forestry/cpn034

Blanc, R., M. Guillemain, J. B. Mouronval, D. Desmonts, and H. Fritz. 2006. Effects of non-consumptive leisure disturbance to wildlife. Revue D'Ecologie-La Terre Et La Vie 61:117-133.

Brown, D. G. 2006. Agent-based models. Pages 7-13 in H. Gist, editor. The earths changing land: an encyclopaedia of land-use and land-cover change. Greenwood, Westport, Connecticut, USA.

Brugnach, M., A. Dewulf, C. Pahl-Wostl, and T. Taillieu. 2008. Toward a relational concept of uncertainty: about knowing too little, knowing too differently and accepting not to know. Ecology and Society 13(2): 30. [online] URL: http:/ /www.ecologyandsociety.org/vol13/iss2/art30/

Cash, D. W., W. C. Clark, F. Alcock, N. M. Dickson, N. Eckley, D. H. Guston, J. Jager, and R. B. Mitchell. 2003. Knowledge systems for sustainable development. Proceedings of the National Academy of Sciences of the United States of America 100:8086-8091. http://dx.doi.org/10.1073/pnas.1231 $\underline{332100}$

Colas, S., M. Fitton, and P. Taxter. 2008. The PROGRESS project: the dynamics of involving the public in managing periurban forests. Pages 165-168 in A. Raschi and S. Trampetti, editors. Proceedings of the Fourth International Conference on Monitoring and Management of Visitor Flows in Recreational and Protected Areas: Management for Protection and Sustainable Development. Pacini Editore Industrie Grafiche, Pisa, Italy.

Cole, D. N. 2006. Visitor and recreation impact monitoring: is it lost in the gulf between science and management? The George Wright Society Forum 23:11-16.

Cole, D. N., M. E. Petersen, and R. C. Lucas. 1987. Managing wilderness recreation use: common problems and potential solutions. General Technical Report INT-230, U.S. Forest Service, Intermountain Research Station, Ogden, Utah, USA. 
Cole, N., editor. 2005. Computer simulation modeling of recreation use: current status, case studies, and future directions. U.S. Forest Service, Fort Collins, Colorado, USA.

Coombes, E. G., A. P. Jones, and W. J. Sutherland. 2008. The biodiversity implications of changes in coastal tourism due to climate change. Environmental Conservation 35:319-330.

http://dx.doi.org/10.1017/S0376892908005134

Farolfi, S., J.-P. Müller, and B. Bonté. 2010. An iterative construction of multi-agent models to represent water supply and demand dynamics at the catchment level. Environmental Modelling \& Software 25:1130-1148. http://dx.doi.org/10.1016/ j.envsoft.2010.03.018

Fernandez-Gimenez, M. E., H. L. Ballard, and V. E. Sturtevant. 2008. Adaptive management and social learning in collaborative and community-based monitoring: a study of five community-based forestry organizations in the western USA. Ecology and Society 13(2): 4. [online] URL: http://ww w.ecologyandsociety.org/vol13/iss2/art4/

Fry, G., B. Tress, and G. Tress. 2007. Integrative landscape research: facts and challenges. Pages 246-268 in J. Wu and R. J. Hobbs, editors. Key topics in landscape ecology. Cambridge University Press, Cambridge, UK. http://dx.doi.org/10.1017/C BO9780511618581.015

Gimblett, R., and H. Skov-Petersen. 2008. Conclusion: monitoring, simulation and management of visitor landscapes. Pages 425-438 in R. Gimblett and H. Skov-Petersen, editors. Monitoring, simulation and management of visitor landscapes. University of Arizona Press, Tucson, Arizona, USA.

Haider, W. 2006. North American idols: personal observations on visitor management frameworks and recreation research. Pages 16-22 in D. Siegrist, C. Clivaz, M. Hunziker, and S. Iten, editors. Third International Conference on Monitoring and Management of Visitor Flows in Recreational and Protected Areas. University of Applied Siences Rapperswil, Rapperswil, Switzerland.

Hanssen, L., E. Rouwette, and M. M. van Katwijk. 2009. The role of ecological science in environmental policy making: from a pacification toward a facilitation strategy. Ecology and Society 14(1): 43. [online] URL: http://www.ecologyandsociety. org/vol14/iss1/art43/

Hill, D., D. Hockin, D. Price, G. Tucker, R. Morris, and J. Treweek. 1997. Bird disturbance: improving the quality and utility of disturbance research. Journal of Applied Ecology 34:275-288. http://dx.doi.org/10.2307/2404876

Holm, T. E., and K. Laursen. 2009. Experimental disturbance by walkers affects behaviour and territory density of nesting Black-tailed Godwit Limosa limosa. Ibis 151:77-87. http://dx. doi.org/10.1111/j.1474-919X.2008.00889.X
Horlick-Jones, T., and J. Sime. 2004. Living on the border: knowledge, risk and transdisciplinarity. Futures 36:441-456. http://dx.doi.org/10.1016/j.futures.2003.10.006

Irvine, R. J., S. Fiorini, S. Yearley, J. E. McLeod, A. Turner, H. Armstrong, P. C. L. White, and R. van der Wal. 2009. Can managers inform models? Integrating local knowledge into models of red deer habitat use. Journal of Applied Ecology 46:344-352. http://dx.doi.org/10.1111/j.1365-2664.2009.01626. $\underline{\mathrm{x}}$

Itami, R. M. 2008. Level of sustainable activity: bottom up vessel traffic management. Pages 155-159 in A. Raschi and S. Trampetti, editors. Proceedings of the Fourth International Conference on Monitoring and Management of Visitor Flows in Recreational and Protected Areas: Management for Protection and Sustainable Development. Pacini Editore Industrie Grafiche, Pisa, Italy.

Itami, R., R. Gimblett, F. Grigel, D. Zelland, and D. McVetty. 2008. Replication, reliability and sampling issues in spatial simulation modeling: a case study exploring patterns of human visitation in Canada's mountain parks. Pages 389-410 in $\mathrm{R}$. Gimblett and H. Skov-Petersen, editors. Monitoring, simulation and management of visitor landscapes. University of Arizona Press, Tucson, Arizona, USA.

Jochem, R., R. van Marwijk, R. Pouwels, and D. G. Pitt. 2008. MASOOR: modeling the transaction of people and environment on dense trail networks in natural resource settings. Pages 269-293 in R. Gimblett and H. Skov-Petersen, editors. Monitoring, simulation and management of visitor landscapes. University of Arizona Press, Tucson, Arizona, USA.

Kerbiriou, C., I. Le Viol, A. Robert, E. Porcher, F. Gourmelon, and R. Julliard. 2009. Tourism in protected areas can threaten wild populations: from individual response to population viability of the chough Pyrrhocorax pyrrhocorax. Journal of Applied Ecology 46:657-665. http://dx.doi.org/10.1111/j.136 5-2664.2009.01646.x

Kleijnen, J. P. C. 1995. Verification and validation of simulation-models. European Journal of Operational Research 82:145-162. http://dx.doi.org/10.1016/0377-2217(94) 00016-6

Lagabrielle, E., A. Botta, W. Daré, D. David, S. Aubert, and C. Fabricius. 2010. Modelling with stakeholders to integrate biodiversity into land-use planning - Lessons learned in Réunion Island (Western Indian Ocean). Environmental Modelling \& Software 25:1413-1427. http://dx.doi.org/10.1016/ j.envsoft.2010.01.011

Lamers, M., B. Ottow, G. Francois, and Y. von Korff. 2010. Beyond dry feet? Experiences from a participatory watermanagement planning case in The Netherlands. Ecology and 
Society 15(1): 14. [online] URL: http://www.ecologyandsociety. org/vol15/iss1/art14/

Liddle, M. J. 1991. Recreation ecology: effects of trampling on plants and corals. Trends in Ecology \& Evolution 6:13-17. http://dx.doi.org/10.1016/0169-5347(91)90141-J

Lynam, T., F. Bousquet, C. Le Page, P. d'Aquino, O. Barreteau, F. Chinembiri, and B. Mombeshora. 2002. Adapting science to adaptive managers: spidergrams, belief models, and multiagent systems modeling. Conservation Ecology 5(2): 24. [online] URL: http://www.consecol.org/vol5/iss2/art24/

Mallord, J. W., P. M. Dolman, A. F. Brown, and W. J. Sutherland. 2007. Linking recreational disturbance to population size in a ground-nesting passerine. Journal of Applied Ecology 44:185-195. http://dx.doi.org/10.1111/j.136 5-2664.2006.01242.x

Marceau, D. 2008. What has been learned from multi-agent based simulation modeling? Pages 411-424 in R. Gimblett and H. Skov-Petersen, editors. Monitoring, simulation and management of visitor landscapes. University of Arizona Press, Tucson, Arizona, USA.

Margerum, R. D. 2002. Collaborative planning - building consensus and building a distinct model for practice. Journal of Planning Education and Research 21:237-253. http://dx.do i.org/10.1177/0739456X0202100302

Maxwell, T., and R. Costanza. 1997. A language for modular spatio-temporal simulation. Ecological Modelling 103:105-113. http://dx.doi.org/10.1016/S0304-3800(97)00103-8

McCool, S. F., R. N. Clark, and G. H. Stankey. 2007. An assessment of frameworks useful for public land recreation planning. General Technical Report PNW-GTR-705, U.S. Forest Service, Pacific Northwest Research Station, Portland, Oregon, USA.

Naylor, L. M., M. J. Wisdom, and R. G. Anthony. 2009. Behavioral responses of North American Elk to recreational activity. Journal of Wildlife Management 73:328-338. http://d x.doi.org/10.2193/2008-102

Nilsen, P., and G. Tayler. 1997. A comparative analysis of protected area planning and management frameworks. Pages 49-57 in S. F. McCool and D. N. Cole, editors. Proceedings of a workshop on Limits of Acceptable Change and related planning processes: progress and future directions. U.S. Forest Service, Rockey Mountains Research Station, Ogden, Utah, USA.

Nowotny, H., P. Scott, and M. Gibbons. 2001. Re-thinking science: knowledge and the public in an age of uncertainty. Polity Press, London, UK.
Opdam, P., M. Broekmeyer, and F. Kistekast. 2009. Identifying uncertainties in judging the significance of human impacts on Natura 2000 sites. Environmental Science \& Policy 12:912-921. http://dx.doi.org/10.1016/j.envsci.2009.04.006

Opdam, P., J. Verboom, and R. Pouwels. 2003. Landscape cohesion: an index for the conservation potential of landscapes for biodiversity. Landscape Ecology 18:113-126. http://dx.do i.org/10.1023/A:1024429715253

Pouwels, R., R. Jochem, and J. Verboom. 2008. Linking ecological and recreation models for management and planning. Pages 253-268 in R. Gimblett and H. Skov-Petersen, editors. Monitoring, simulation and management of visitor landscapes. University of Arizona Press, Tucson, Arizona, USA.

Pröbstl, U., P. A. M. Visschedijk, and H. Skov-Petersen. 2008. Agent-based modelling: views from the management perspective. Pages 239-252 in R. Gimblett and H. SkovPetersen, editors. Monitoring, simulation and management of visitor landscapes. University of Arizona Press, Tucson, Arizona, USA.

Refsgaard, J. C., and H. J. Henriksen. 2004. Modelling guidelines - terminology and guiding principles. Advances in Water Resources 27:71-82. http://dx.doi.org/10.1016/j.advwa $\underline{\text { tres.2003.08.006 }}$

Ritzema, H., J. Froebrich, R. Raju, C. Sreenivas, and R. Kselik. 2010. Using participatory modelling to compensate for data scarcity in environmental planning: a case study from India. Environmental Modelling \& Software 25:1450-1458. http://d x.doi.org/10.1016/j.envsoft.2010.03.010

Scheller, R. M., J. B. Domingo, B. R. Sturtevant, J. S. Williams, A. Rudy, E. J. Gustafson, and D. J. Mladenoff. 2007. Design, development, and application of LANDIS-II, a spatial landscape simulation model with flexible temporal and spatial resolution. Ecological Modelling 201:409-419. http://dx.doi.o rg/10.1016/j.ecolmodel.2006.10.009

Simon, C., and M. Etienne. 2010. A companion modelling approach applied to forest management planning. Environmental Modelling \& Software 25:1371-1384. http://d x.doi.org/10.1016/j.envsoft.2009.09.004

Skov-Petersen, H. 2008. The role of agent-based simulation in recreational management and planning. Pages 33-39 in A. Raschi and S. Trampetti, editors. Proceedings of the Fourth International Conference on Monitoring and Management of Visitor Flows in Recreational and Protected Areas: Management for Protection and Sustainable Development. Pacini Editore Industrie Grafiche, Pisa, Italy. 
Souchère, V., L. Millair, J. Echeverria, F. Bousquet, C. Le Page, and MEtienne. 2010. Co-constructing with stakeholders a role-playing game to initiate collective management of erosive runoff risks at the watershed scale. Environmental Modelling \& Software 25:1359-1370. http://dx.doi.org/10.1016/ j.envsoft.2009.03.002

Stankey, G. H., R. N. Clark, and B. T. Bormann. 2005. Adaptive management of natural resources: theory, concepts and management institutions. General Technical Report PNW-GTR-654, U.S. Forest Service, Northwest Research Station, Portland, Oregon, USA.

Star, S. L., J. R. Griesemer. 1989. Institutional ecology, 'translations' and boundary objects: amateurs and professionals in Berkeley's Museum of Vertebrate Zoology, 1907-39. Social Studies of Science 19:387-420. http://dx.doi. org/10.1177/030631289019003001

Sturtevant, B. R., A. Fall, D. D. Kneeshaw, N. P. P. Simon, M. J. Papaik, K. Berninger, F. Doyon, D. G. Morgan, and C. Messier. 2007. A toolkit modeling approach for sustainable forest management planning: achieving balance between science and local needs. Ecology and Society 12(2): 7. [online] URL: http://www.ecologyandsociety.org/vol12/iss2/art7/

Sutherland, W. J. 2007. Future directions in disturbance research. Ibis 149:120-124. http://dx.doi.org/10.1111/j.1474919X.2007.00673.X

Sutherland, W. J., S. Armstrong-Brown, P. R. Armsworth, T. Brereton, J. Brickland, C. D. Campbell, D. E. Chamberlain, A. I. Cooke, N. K. Dulvy, N. R. Dusic, M. Fitton, R. P. Freckleton, H. C. J. Godfray, N. Grout, H. J. Harvey, C. Hedley, J. J. Hopkins, N. B. Kift, J. Kirby, W. E. Kunin, D. W. Macdonald, B. Marker, M. Naura, A. R. Neale, T. Oliver, D. Osborn, A. S. Pullin, M. E. A. Shardlow, D. A. Showler, P. L. Smith, R. J. Smithers, J. L. Solandt, J. Spencer, C. J. Spray, C.D. Thomas, J. Thompson, S. E. Webb, D. W. Yalden, and A. R. Watkinson. 2006. The identification of 100 ecological questions of high policy relevance in the UK. Journal of Applied Ecology 43:617-627. http://dx.doi.org/10. 1111/j.1365-2664.2006.01188.x

Termorshuizen, J. W., and P. Opdam. 2009. Landscape services as a bridge between landscape ecology and sustainable development. Landscape Ecology 24:1037-1052. http://dx.doi.org/10.1007/s10980-008-9314-8

Thompson Klein, J. 2004. Prospects for transdisciplinarity. Futures 36:515-526. http://dx.doi.org/10.1016/j.futures.2003. $\underline{10.007}$

van Marwijk, R. 2008. Walkers' perspectives on nature management strategies: nature restoration in a national park. Pages 113-126 in H. de Haan and R. van der Duim, editors. Landscape, leisure and tourism: socio-spatial studies in experiences, practices and policies. Eburon, Delft, The Netherlands.

van Marwijk, R. 2009. These routes are made for walking. Understanding the transactions between nature, recreational behaviour and environmental meanings in Dwingelderveld National Park, the Netherlands. Dissertation. Wageningen University, Wageningen, The Netherlands.

Verboom, J., R. Foppen, P. Chardon, P. Opdam, and P. Luttikhuizen. 2001. Introducing the key patch approach for habitat networks with persistent populations: an example for marshland birds. Biological Conservation 100:89-101. http:// dx.doi.org/10.1016/S0006-3207(00)00210-X

Verboom, J., and R. Pouwels. 2004. Ecological functioning of ecological networks: a species perspective. Pages 56-72 in R. Jongman and G. Pungetti, editors. Ecological networks and greenways. Concept, design, implementation. Cambridge University Press, Cambridge, UK. http://dx.doi.org/10.1017/C BO9780511606762.006

Voinov, A., and F. Bousquet. 2010. Modelling with stakeholders. Environmental Modelling \& Software 25:1268-1281. http://dx.doi.org/10.1016/j.envsoft.2010.03.007

Warnken, J., and R. Buckley. 1998. Scientific quality of tourism environmental impact assessment. Journal of Applied Ecology 35:1-8. http://dx.doi.org/10.1046/j.1365-2664.1998.00288. $\underline{\mathrm{x}}$

Wilhere, G. F. 2002. Adaptive management in habitat conservation plans. Conservation Biology 16:20-29. http://dx. doi.org/10.1046/j.1523-1739.2002.00350.x

Williams, B. K., R. C. Szaro, and C. D. Shapiro. 2007. Adaptive management: the U.S. Department of the Interior technical guide. Adaptive Management Working Group, U.S. Department of the Interior, Washington, D.C., USA.

Yalden, P. E., and D. W. Yalden. 1990. Recreational disturbances of breeding Golden Plovers Pluvialis apricarius. Biological Conservation 51:243-262. http://dx.doi.org/10.101 6/0006-3207(90)90111-2

Young, J., A. Watt, P. Nowicki, D. Alard, J. Clitherow, K. Henle, R. Johnson, E. Laczko, D. McCracken, S. Matouch, J. Niemela, and C. Richards. 2005. Towards sustainable land use: identifying and managing the conflicts between human activities and biodiversity conservation in Europe. Biodiversity and Conservation 14:1641-1661. http://dx.doi.or $\mathrm{g} / 10.1007 / \mathrm{s} 10531-004-0536-\mathrm{Z}$ 